\title{
TUNA BAITFISH AND THE POLE-AND-LINE FISHERY IN EASTERN INDONESIA - AN OVERVIEW
}

\author{
Nurzali Naamin" and Bachtiar Gafa*'
}

\begin{abstract}
Skipjack tuna is the principal species in the pole-and-line fishery in the eastern part of Indonesia. The species accounts for 85 to $95 \%$ of pole-and-line landings and 80 to $90 \%$ of total tuna landings. The pole-and-line fishery relies upon an adequate supply of liave baitfish. There are about 16 species from five families. namely Engraulididae. Clupeidae, Scombridae and Carangidae of important tuna baitfish in eastern Indonesia. The baitfish catch cought by bagans and bouke-ami in Maluku and other part of eastern Indonesian waters consist of $75 \%$ "ikan puri" anchovy Stolephorus spp.. 10\% "tatare" horse mackerel, Rastrelliger spp., 10\% of "make" Sardinella spp. and about 5" of other small pelagic fish. The major constraint to the existing fishery is an irregular supply of baitfish and the pole-and-line fishery loses approximately $40 \%$ of effective fishing days due to lack of suitable baitfish. There is a decreasing trend in the ratio of baitfish utilization to the tuna catch from around $9.10 \mathrm{~kg}$ of tuna skipjack per $\mathrm{kg}$ of baitfish (1968.1971) to $3.5 \mathrm{~kg}$ of tuma skipjack per $\mathrm{kg}$ of baitfish (1986-1995).
\end{abstract}

KEYWORDS: tuna baitfish, pole-and-line, skipjack

\section{INTRODUCTION}

The tuna and skipjack fisheries of Indonesia are important sources of export income (second after shrimp). employment, animal protein, and raw materials for canning and katsuobushi indus. tries, particularly in eastern Indonesia. The volume of export of tuna and skipjack increased from 26.059 tonnes in 1986 to 100,070 tones in 1996 with a value that increased from US\$21.677 million in 1986 to US\$525.000 million in 1996.

The small-scale or artisanal fisheries of eastern Indonesia produced almost $80 \%$ of the tuna and skipjack catches. The pole-and-line fishery for skipjack (Katsuwonus pelamis) and yellowfin (Thunnus albacares) tunas are important commercial fisheries in eastern Indonesia. The pole-andline method relies upon an adequate and regular supply of live baitfish. The major constraint to the existing fishery is the irregular supply of baitfish and the pole-and-line fishery loses approximately $40 \%$ of effective fishing days due to lack of suitable baitfish.

The supply of baitfish to the pole-and-line fleet comes from a totally separate fishery, in both space and time, than for tunas. Baitfish are caught in sheltered coastal waters at night by "bagan" (lift net) or by the pole-and-line vessel using a "basnig" net. Light is used to attract the baitfish to the fishing platform before they are captured in fine. meshed nets. The baitfish are loaded into bait tanks in the pole-and-line vessels where they are kept alive ready for the next day's fishing.

\section{THE POLE-AND-LINE FISHERY IN EAST- ERN INDONESIA}

\section{History of the Fishery}

Japanese fishermen first introduced pole-andline fishing to Indonesia in 1918 to catch Katsuobushi or "Ikan Kayu" in the North of Sulawesi Island (now North Sulawesi Province). No data are available about the development of the pole-and-line fisheries from that time until 1950. From 1951 to 1967 there are data for the artisanal 30 GT pole-and-liners based in Ambon.

In its development the pole-and-line fishery can be classified into three groups, ie. (1) industrial pole-and-line fishery, (2) large-scale pole-andline fishery and (3) artisanal pole-and-line fishery. It is considered an industrial pole-and-line fishery if fishing is with vessels over $100 \mathrm{GT}$, with a freezing capacity. The artisanal pole-and-line fishery uses wooden vessels of 5 GT called funai or rurehe, while large-scale pole-and-line fishing uses mostly wooden or fibreglass vessels of 10 to $100 \mathrm{GT}$.

\section{The Industrial Pole-and-line Fishery}

Four companies were included in this group, ie: (l) P.T. East Indonesia ( a joint- venture be-

'Research Institute for Marine Fisheries 
tween Indonesia and Japan) based in Ternate; (2) P.T. Usaha Mina (a State Enterprise) based in Sorong: (3) P.N. Perikanan Maluku (a State Enterprise) based in Ambon; and (4) P.T. Multitranspeche Indonesia (a joint venture between Indonesia and France) based in Biak. The four companies operate 10 vessels of over $100 \mathrm{GT}$, ie. 2 vessels of $100 \mathrm{GT}, 2$ vessels of $200 \mathrm{G}$ T, and 6 vessels of 300 GT. The fishing grounds of these industrial pole-and-liners are the waters adjacent to their home bases.

PT. East Indonesia began operations in 1974 with two types of Japanese vessels: 100 G'T and 190 GT. Since 1978 only two 190 GT vessels have been operated. Each vessel in bay of Waigeo Island carries baiting out every day and fishing for tuna and skipjack takes place to the north and west of this island. Fishing ceased in 1983 due to management problems.

P'T. Usaha Mina was established in 1973 and began its activities in 1976 with 15 pole-and-liners of $30 \mathrm{G}$ 'T, then increased to 30 vessels in 1977. In 1980, a 300 G'T pole-and-liner was added to the fleet, in 1981 a 100 GT vessel, and in 1982 another 300 GT vessel. The company also has two 600 GT mother ships used as carrier boats. Due to inefficiencies the larger pole-and-liner is no longer used as a catcher boat. but has been converted to a carrier boat.

Operating with four larger $400 \mathrm{GT}$ pole-andliners, PT. Multitranspeche Indonesia is the only company that has a cannery for processing their pole-and-line and purse seine catches. This company went bankrupt in 1993 and since then has changed ownership three times. In the last few years the P.T. Jayanti Group has run the company.

\section{The Large-scale Pole-and-line Fishery}

\section{(1) The large-scale pole-and-line fishery in Irian Jaya}

The first experimental pole-and-line fishing in north Irian Jaya was contracted by UNDP and carried out in 1971 by the Japanese Company Nichiro Gyogyo Kaisha. Surveys were done in the areas of Sorong, Biak and Jayapura. The results show that the best place to develop pole-and-line fishing were the areas of Sorong and Waigeo Island, where the skipjack tuna fishing grounds are not too far from the baitfishing grounds.
The State Enterprise PT. Usaha Mina was established in 1973 and began its activities in 1976 , with 1530 GT pole-and-liners, increased to 30 vessels in 1977. They preserve the catch with ice. From 1978 to 1984 PT. Usaha Mina operated com mercially in Sorong. They extended their fishing operations from Sorong to Labuha where they established a fishing base in 1987. This was followed by the establishment of bases in Gorontalo in 1988 and Luwuk in 1989. Further expansion to the southeast of Sorong Base included Fak-Fak (1990). Kaimana (1991) and Tual (1994). There was a plan to expand to East Timor in 1996 but did not succeed.

PT. Usaha Mina changed to a NES (Nucleus Estate for Smallholders) system in 1985, when it became as the nucleus and small-scale fishermen as the plasm in the new areas developed as mentioned above. PT. Usaha Mina provided all the needs of the fishermen in their fishing operations (skill, capital, engine, fuel and ice) except for the boat. In turn the plasm fishermen have to sell their catches to PT. Usaha Mina.

\section{(2) The large-scale pole-and-line fishery in Maluku}

\section{- Ternate}

Pole-and-line fishing in Ternate known as huhate has existed since a long time. During World War II. this small island had a Katsuobushi or Ikan Kayu factory. Huhate - wooden pole-and-liners of 10 to $100 \mathrm{GT}$ are all based in Ternate and the fishing grounds are located in the vicinity of Ternate and Tidore Islands, and between those islands and Halmahera, where the bait is caught.

\footnotetext{
- Ambon

The fishing grounds of pole-and-liners in Ambon and adjacent areas have been known for many years. The Dutch had developed a fishing enterprise "Stichting Voor de Zee Vissery" which became, after independence, the "Yayasan Perikanan Laut" and finally the State Enterprise P.N. Perikani Maluku. Besides this State Enterprise, 10 pole-and-liners of 30 GT run by cooperatives, and 17 pole-and-liners belong to private fishing companies, were operated from 1968 to 1981.
} 
(3) The large-scale pole-and-line fishery in Sulawesi

Tuna fishing is a very old activity in Sulawesi. especially that of pole-and-line fishery which was probably introduced by Japanese fishermen in 1918 to process Katsuobushi or Ikan Kayu in the northern part of the island. There are two Prov. inces that developed pole-and-line fishing in Sulawesi. ie. North Sulawesi and Southeast Sulawesi. Aertembaga near Bitung is the main pole-and-liners home base in North Sulawesi, besides Gorontalo, Kemah and Manado. In southeast Sulawesi, Kendari, is the main pole-and-linefishing base. Bau-Bau and Kolaka are fishing bases for small pole-and-liners.

The state enterprise fishing company, P.N. Perikani Aertembaga was established in 1966 and commenced operations in 1967. From 1967 to 1977 the company had 10 to 12 vessels of 30 G'T in operation. However, from 1973 to 1978. due to mismanagement. the number of operational days at sea was very low. The fleet increased to 20 boats in 1979 and since 1980 30 vessels have fished regularly.

There are few private fishing companies that operate more than 10 vessels over 60 GT. P.T. Sari Cakalang appears to be a progressive, integrated operation and is the only fishing company in Bitung that still operates its own fleet. The company owns five pole-and-line vessels between 56 and $83 \mathrm{GT}$ and buys from six other privately owned boats. The operation processes 400-500 tonnes of skipjack to katsuobushi, 100-200 tonnes exported frozen, 200 tonnes sold to Bitung canneries and 25-50 tonnes sold fresh to the local market. The company produces fishmeal from the Katsuobushi processing waste, and has its own Decapterus harvesting vessels to assure bait supply.

\section{The Artisanal Pole-and-line Fishery}

The artisanal pole-and-liners of Indonesia include vessels called funai or rurehe in Bitung/ Ternate and Ambon respectively. In Labuha, there is another type of artisanal pole-and-line boat of similar design known as a bogogara. These vessels are 10-12 $\mathrm{m}$ in length (5 GT) of an open skiff construction with a central baithold in the belly of the hull. They operate with a crew of $6-12$ on single day fishing trip supplying coastal communities with fresh skipjack. The boats are powered by outboard engines of 20-40 HP. Traditional baithold circulation is generated by means of holes through the hull assisted by a pump on some funai. The pump removes water from the baithold and pumps it overboard while fresh seawater enters through the holes in the bottom of the hull. The pump is also used to power water sprayers during fishing operations.

The three bogogara boats in Labuha are com. bination fishing vessels of about $10 \mathrm{~m}$. The boats catch their own bait with a lift net for pole-and. line operations and carry handlines used for large tunas during low catching periods. The rurehe boats of Banda Island are similar to funai in size and construction. The main difference in the fishing is that the Banda Islands do not have an abundance of typical tuna baitfish, (anchovies and sardines). The rurehe fishermen therefore capture damselfish with a large A-frame lift net and these are used for chum or directly as live bait.

\section{The Fishing Grounds and Fishing Bases of the Pole-and-line Fishery}

Pole-and-line fishing has only developed in nine provinces in the eastern part of Indonesia: West Nusa Tenggara, East Nusa Tenggara, East Timor, South Sulawesi, Southeast Sulawesi, Central Sulawesi, North Sulawesi, Maluku and Irian Jaya. Attempts to develop pole-and-line fishing in western Indonesia have not succeeded. Eastern Indonesia is a vast region of over three million square $\mathrm{km}$ and makes up about $52 \%$ of the 5.8 million square $\mathrm{km}$ of Indonesian seas. The region can be broken down into four major pole-and-linefishing areas: Flores Sea, Sulawesi and adjacent waters, Maluku and Irian Jaya. Major fishing bases include Maumere, Larantuka and Kupang in Nusa Tenggara; Kendari, Gorontalo and Bitung in Sulawesi; Labuha, Ternate, Ambon and Tual in Maluku; and Biak, Sorong, Kaimana and Fak. Fak in Irian Jaya.

\section{Landings, Number of Vessels, CPUE and kg tuna/kg baitfish}

\section{Landings and number of vessels}

Skipjack tuna is the principal species caught by the pole-and-line fishery. The species accounts for $85-95 \%$ of pole-and-line landings and $80-90 \%$ of total tuna landings. Landings of skipjack increased from 73,677 tonnes in 1992 to 77,346 tonnes in 1993 and to 81,219 tonnes in 1994. The 
1997 landings totalled about 106,677 tonnes. Yel lowfin tuna landings from pole-and-liners in. creased slightly from 5,319 tonnes in 1992 to 5,830 tonnes in 1994. The number of pole-and-liners based in eastern Indonesia was 823 vessels in 1993 and 820 vessels in 1994 .

\section{CPUE and kg tuna/kg baitfish}

Catch per unit effort (CPUE) data from pri. vate $30 \mathrm{GT}$ pole-and-liners based in Ambon is available from 1951 to 1967 (Table 1). CPUE ranged from 360 to $615 \mathrm{~kg}$ per vessel per day and good CPUE (around 600) occurred in 1952 and from 1957 to 1962 . From 1963 to 1967 the CPUE decreased slightly to lower than $580 \mathrm{~kg}$ per vessel per day. The CPUE data of P.T. Perikani Maluku (PPM) from 1968 to 1981 (Table 1) fluctuated from 418 to $1052 \mathrm{~kg}$ per vessel per day. The lower CPUE (around 430) only occurred in 1968 and 1969. From 1970 to 1981 the CPUE fluctuated from 640 to 1052 $\mathrm{kg}$ per vessel per day but mostly around 700. Data from the State Enterprise P.T. Perikani Aertembaga (P'T. AGA) is available from 1967 to 1982 and catches fluctuated from 440 to $1090 \mathrm{~kg}$ per vessel per day.

PT. Usaha Mina has a long series of C.PUE data from its fishing trials in 1973 until 1997. These can be grouped into two periods: (1) before using rumpon (payaos) (1973-1984) and after using rumpon (1985-997). After using payaos the CPUE doubled. Soepanto (1997) stated that the use of rumpon (payaos) increased the CPUE about 50\% and reduced the use of fuel by about $30 \%$.

\section{LIVE BAITFISHERIES}

As mentioned above skipjack tuna is the principal species in the pole-and-line fishery. The species accounts for 85 to $95 \%$ of pole-and-line landings and 80 to $90 \%$ of total tuna landings. This pole-and-line fishery relies upon an adequate supply of live baitfish. The major constraint to the existing fishery is an irregular supply of baitfish and the pole-and-line fishery loses approximately $40 \%$ of effective fishing days due to lack of suitable baitfish. Limited knowledge about the size of the baitfish resources has been of great concern in relation to fleet expansion.

\section{Literature Review}

Surveys for tuna baitfish have been undertaken in eastern Indonesia waters since 1970 by
FAO UNDP Project, the Research Institute for Marine Fisheries Jakarta and Ambon. LIPI-Ambon, University of Pattimura, as well as foreign advisers with expertise in pole-and-line fishing. The surveys located many baitgrounds in Sulawesi, Maluku and Irian Jaya that were adjacent to tuna fishing grounds (Kawakami-FAO, 1974: Subani, 1982; Marcille et al., 1984; Uktolseja, 1984: (iafa \& Subani, 1987, 1991; Andamari et al., 1987; Rumarupute et al.. 1987, Wahyuono \& Rusmadji. 1987: Banjar \& Talaohu, 1987; Banjar \& Andamari. 1990; Hurasan et al.. 1990; Suma. dhiharga, 1990: Edrus et al., 1992; Itano, 1993; Tubalawony \& Siahainenia, 1994). The earlier surveys allowed the establishment of state run fishing companies at Bitung, Sorong, Ambon and Bacan. The Nucleus Estate for Smallholders (NES) System was established by the Government in the 1980 s to promote the integration of artisanal fish. ermen into the activities of the tuna bases and the government provided incentive, loans for vessel purchase and extension services as well as physical infrastructure (Uktolseja, 1989). None of the above mentioned research included studies of baitfish stock assessment.

The Research Institute for Marine Fisheries in Indonesia has undertaken considerable research into various aspects of baitfishing as follows:

* Studies of live bait fishing techniques in Maluku (Gafa \& Subani, 1987, 1991)

* Analyses of the species composition of baitfishes caught in Ambon (Andamari et al., 1987)

* Detailed surveys of catch levels and seasonal bait availability (Rumarupute et al., 1987; Gafa \& Subani. 1991; Wahyuono \& Rusmadji. 1987).

* Detailed biological studies of Encrasicholina devisi and $E$. heterolobus in the Ambon region (Bandjar \& Talaohu, 1987; Bandjar \& Andamari, 1990).

* Studies of Sardinella fimbriata in Maluku (Hurasan et al., 1990).

Dr. Sumadhiharga of LIPI and Pattimura University at Ambon have also carried out biological research on Stolephorus species in Ambon Bay and expertise exists in these institutions although much of the work remains unpublished.

Itano (1993) carried out a field survey of tuna baitfish capture and handling techniques in east. ern Indonesia. This project was instigated by ACIAR through the Western Pacific Fisheries 
Gafa, B. and Subani, W. 1991. Fishing gear. fishing season, fishing areas, exploitation level and development of live bait in Maluku waters. J. Prnelitian Perikanan Laut 61: 33-50.

Gafa, B., Merta, I.G.S., Barus, H.R. and Amin, E.M. 1993. Factors Affecting the Decline of Tuna and Skipjack Catch in the North Sulawesi Waters. Survey Report - RIMF - Jakarta (Mimeo).

Hampton. J. 1994. A Review of Tuna Fishery Interastion Issues in the Western and Central Parific Ocean. Interaction of Pacific Tuna Fisheries. Proceedings of the first FAO Expert Consultation on Interac. tions of Pacific Tuna Fisheries. Rome. p 138-157.

Hurasan, M.S., Bandjar, H. and Syam. A.R. 1990. Analysis on biological aspect of Sardinella fimbriata in Paperu, Saparua Bay. J. Penelitian Perikanan Laut 55: 29-39.

Itano, D. 1993. The Development of the Indonesian Pole. and-line Fishery in Relation to the Efficient Utilisation of Live Baitfish Resources. Phase I. Field Survey of Tuna Baitfish Capture and Handling Techniques in Eastern Indonesia. Unpublished Re. port WPFCC Consultation Committee. Manila. Philippines.

Kawakami-FAO. 1974. Bait Fish and Skipjark Survey in Western Nusa Tenggara Waters. Laporan Penelitian Perikanan Laut (1)

Marcille, J., Boely, T., Unar, M., Merta, I.G.S. Sadhotomo, B. and Uktolseja, J.C.B. 1984. Tuna fishing in Indonesia. Travaux et documents 181: 1. 125.

Naamin, N. 1994. Indonesian Fisheries for Yollowfin Tuna in the Western Pacific - Eastern Indonesia. Working paper for the 4th Western Pacific Tuna Research Group Meeting, Koro - Palau, August 9. 11,1994

Naamin, N. and Bahar, S. 1994. Interaction in the Yel. lowfin Tuna Fisherie's of the Eastern Part of the In. donesian Waters. Interaction of Pacific tuna fisher- 1es. Consultation on Interactions in Pacific Tuna Fisheries. Rome. p 199-212.

North Sulawesi Fisheries Service. 1994. Fisheries Statistic's of North Sulawesi 1994. Manado.

Soepanto. 1997. Fishing and Resource Management Partnerships Undertaken by P.T. Usaha Mina (Persero), Indonesia. Paper Presented at the Semi. nar on Smart Partnership for Sustainability in the Fishing Industry, 26-28 November 1997. Femingi Hotel Penang. Malaysia

Subani. W. 1982. Live Bait Fishes as Supporting Skipjack Fisheries. (A review of live bait survey in the Eastern Part of Indonesia, west Nusa Tenggara and western part of Indonesian waters). Mar. Fish. Res. Rep. 24: $1 \cdot 25$.

Sumadhiharga, O.K. 1993. Biologi dan pengelolaan ikan teri Stolephorus spp. sebagai ikan umpan di Teluk Ambon. Prosiding Simposium Perikanan Indonesia I. 25-27 Agustus 1993. Jakarta. Indonesia 1993/2. p 579-587.

Rumahrupute, B., Syukur, M. and Letelay, J. 1987. Survey on fish bait in Central Maluku. J. Penelitian Perikanan Laut 43: 81.87.

Tubalawony, S. and Siahainenia. L. 1994. Studi Beberapa Aspek Biologi Ikan Umpan di Perairan Pulau Saparua. Pusat Studi Pengelolaan Sumber Alam dan Lingkungan. Universitas Pattimura . Ambon.

Uktolseja, J.C.B. and Merta, I.G.S. 1984. Present Development Indonesia Tuna Fisheries. (FAO/UNDIP/ IPTP. Andhoc Worksop on the Stock Assessment of Tuna in the Indo-Pacific Region. Jakarta 20-23 August 1984. IPTP/84/TWS/2A)

Uktolseja, J.C.B. 1989. The Status of the Indonesian Tuna Fisheries. Paper presented at the Third Southeast Asian Tuna Conference, 22-24 August. 1989. Denpasar, Bali, Indonesia.

Wahyuono, H. and Rusmadji. 1987. Lift net fishery in Jepara Waters. J. Penelitian Perikanan Laut 43: 81 . 87. 


\section{The Status of Baitfish Fisheries in Eastern Indonesia}

In the last decade, the major constraint to the existing pole-and-line fishing has been the irregular supply of baitfish and the pole-and-line fishery loses approximately $40 \%$ of effective fishing days due to lack of suitable baitfish. The fishing bases of the pole-and-line fisheries run by the State Enterprise Fishing Companies, namely P.T. Perikanan Aertembaga in Bitung (North Sulawesi) and PPM (Perum Perikanan Maluku) in Ambon were set up in these areas because baitfish were abundant from 1960 to 1980 . But in the last ten years it has become very difficult to obtain tuna baitfish in Ambon Bay and in Bitung and adja. cent waters. Therefore, these two State Enterprise Fishing Companies no longer conduct fishing us. ing their own pole-and-line boats, and lately, their activities have been restricted to collecting tuna/ skipjack from artisanal catches.
The only State Enterprise Fishing Company that still survives is P.T. Usaha Mina based in Sorong. This semi-government fishing company has put a lot of effort into expanding their fleet to remote areas where there is still availability of tuna baitfish, such as Labuha, Gorontalo, Fak-Fak and Tual. The company has also put a lot of effort into reducing the use of bait, by deploying rumpon or payaos. Data on baitfish used by PT. Usaha Mina are given in Table 3.

Limited knowledge about the size of the baitfish resources is of great concern for the poleand-line fishing companies and the government in relation to fleet expansion and for baitfish conservation and management. Therefore the Indonesian Government asked for the assistance of the Australian Government and specifically CSIRO, which has a great deal of baitfish expertise and experience from research in the South Pacific Region.

Table 3. Baitfish used by PT. Usaha Mina based at Sorong (Unit: Bucket).

\begin{tabular}{|c|c|c|c|c|c|c|c|c|c|c|c|c|c|}
\hline \multirow{2}{*}{ Year } & \multicolumn{12}{|c|}{ Months } & \multirow{2}{*}{ Total } \\
\hline & Jan. & Feb. & Mar. & Apr. & May & Jun. & Jul. & Aug. & Sep. & Oct. & Nov. & Dec. & \\
\hline 1990 & 5.544 & 8.410 & 11.640 & 13.12 & 17.15 & 15.06 & 17.55 & 22.640 & 24.4 & 28.990 & 24.39 & 23.48 & 212.364 \\
\hline 1991 & 22.2 & 15.61 & 15.12 & 17.35 & 24.15 & 25.05 & 24.930 & 19.86 & 14.27 & 19.53 & 25.500 & 15.78 & 239.342 \\
\hline 1992 & 14.05 & 7.219 & 14.24 & 13.68 & 20.640 & 11.95 & 15.5 & 12.84 & 19.39 & 21.83 & 20.16 & 19.12 & 190.617 \\
\hline 1993 & 7.409 & 12.26 & 12.5 & 13.63 & 15.09 & 17.060 & 14.64 & 9.100 & 12.930 & 15 & 16.81 & 7.730 & 154.139 \\
\hline 1994 & (6.15:) & 8.835 & 10.52 & 6.449 & 8.118 & 8.033 & 9.226 & 10.46 & 12.5 & 16.35 & 16.6 & 11.45 & 124.682 \\
\hline 1995 & 8.273 & 10.03 & 13.84 & 11.71 & 11.23 & 8.309 & 5.846 & 2.074 & 1.448 & 7.871 & 8.517 & 2.276 & 91.414 \\
\hline 1996 & 9.960 & 4.00() & 5.103 & 6.771 & 5.255 & 5.214 & 5.197 & 4.514 & 3.591 & 9.579 & 9.017 & 5.390 & 73.591 \\
\hline 1997 & 5.578 & 4.0055 & 3.444 & 3.275 & 2.596 & 2.157 & 2.544 & 1.366 & 3.946 & 4.96 & 6.555 & 4.462 & 44.89 \\
\hline
\end{tabular}

\section{REFERENCES}

Andamari, R., Hasan, N. and Zubaidi, T. 1987. Composition of bait fishes cought by Bagan in Baguala Bay, Ambon Island. J. Penelitian Perikanan Laut 36: 51 57.

Banjar, H. and Talaohu, S.H. 1987. A study on Stolephorus heterolobus and its relation to bait fisheries in Tulehu Bay (Central Moluccas). J. Penelitian Perikanan Laut 44: 25-30.

Banjar, H. and Andamari, R. 1990. Sex ratio, gonad maturity and fecundity of anchovies Stolephorus devisi in Saparua. J. Penelitian Perikanan Laut 55: $1 \cdot 7$.

Edrus, I. N., Syam, A.R. and Sui, La. 1992. Potency, utilisation and development prospects of coral reef fisheries in Banda Island, Central Maluku. $J$. Penelitian Perikanan Laut 74: 40-60.

Edrus, I.N., Ronny, S.A. and Bandjar, H. 1992. Potency on ornamental fish and coral reef in the outlet of Ambon Island Waters. J. Penelitian Perikanan Laut 70: $37-51$.

FAO. 1974. Report to the Government of Indonesia on Survey for Bait and Skipjack Fishing, Based on the Work of Z. Ilawakarni. FAO, Rome. p 1-38.

Gafa, B. 1986. Live bait fishes as a supporting pole and line fisheries in Maluku Waters. J. Penelitian Perikanan Laut 34: 21-29.

Gafa, B. and Subani, W. 1986. Fishing gear, fishing season, fishing areas, exploitation level and development of live bait in Maluku waters. J. Penelitian Perikanan Laut 60: 33-50. 
Gafa, B. and Subani, W. 1991. Fishing gear, fishing season, fishing areas, exploitation level and development of live bait in Maluku waters. J. Prnelitian Perikanan Laut 61: 33-50.

Gafa, B., Merta, I.G.S., Barus, H.R. and Amin. E.M. 1993. Factors Affecting the Decline of Tuna and Skipjack Catch in the North Sulawesi Waters. Sur. vey Report - RIMF - Jakarta (Mimeo).

Hampton. J. 1994. A Review of Tuna Fishery Interartion Issues in the Western and Central Parific Ocean. Interaction of Pacific Tuna Fisheries. Proceedings of the first FAO Expert Consultation on Interactions of Pacific Tuna Fisheries. Rome. p 138.157.

Hurasan, M.S., Bandjar, H. and Syam, A.R. 1990. Analysis on biological aspect of Sardinella fimbriata in Paperu, Saparua Bay. J. Penelitian Perikanan Laut 55: 29-39.

Itano, D. 1993. The Development of the Indonesian Pole and-line Fishery in Relation to the Efficient Utilisation of Live Baitfish Re'soures. Phase I. Field Survey of Tuna Baitfish Capture and Handling Techniques in Eastern Indonesia. Unpublished Re. port WPFCC Consultation Committee. Manila. Philippines.

Kawakami-FAO. 1974. Bait Fish and Skipjark Survey in Western Nusa Tenggara Waters. Laporan Pene. litian Perikanan Laut (1)

Marcille, J., Boely, T., Unar, M., Merta, I.G.S. Sadhotomo, B. and Uktolseja, J.C.B. 1984. Tuna fishing in Indonesia. Travaux et doruments 181: 1. 125

Naamin, N. 1994. Indonesian Fisheries for Yellowtin Tuna in the Western Pacifir - Eastern Indonesia. Working paper for the 4 th Western Pacific Tuna Research Group Meeting, Koro - Palau, August 9. 11. 1994 .

Naamin, N. and Bahar, S. 1994. Interaction in the Yel. lowfin Tuna Fisheries of the Eastern Part of the In. donesian Waters. Interaction of Pacific tuna fisher- ies. Consultation on Interactions in Pacific Tuna Fisheries. Rome. p 199-212.

North Sulawesi Fisheries Service. 1994. Fisheries Statistic's of North Sulawesi 1994. Manado.

Soepanto. 1997. Fishing and Resource Management Partnerships Undertaken by P.T. Usaha Mina (Prrsero), Indonesia. Paper Presented at the Semi. nar on Smart Partnership for Sustainability in the Fishing Industry. 26-28 November 1997. Femingi Hotel Penang. Malaysia

Subani. W. 1982. Live Bait Fishes as Supporting Skip jack Fisheries. (A review of live bait survey in the Eastern Part of Indonesia, west Nusa Tenggara and western part of Indonesian waters). Mar. Fish. Res. Rep. 24: 1.25.

Sumadhiharga, O.K. 1993. Biologi dan pengelolaan ikan teri Stolephorus spp. sebagai ikan umpan di Teluk Ambon. Prosiding Simposium Perikanan Indonesia I. 25.27 Agustus 1993. Jakarta. Indonesia 1993/2. p 579-587.

Rumahrupute, B., Syukur, M. and Letelay, J. 1987 Survey on fish bait in Central Maluku. J. Penelitian Perikanan Laut 43: 81-87.

Tubalawony, S. and Siahainenia. L. 1994. Studi Beberapa Aspek Biologi Ikan Umpan di Perairan Pulau Saparua. Pusat Studi Pengelolaan Sumber Alam dan Lingkungan. Universitas Pattimura . Ambon.

Uktolseja, J.C.B. and Merta, I.G.S. 1984. Present Development Indonesia Tuna Fisheries. (FAO/UNDIP/ IPTP. Andhoc Worksop on the Stock Assessment of Tuna in the Indo-Pacific Region. Jakarta 20-23 August 1984. IPTP/84/TWS/2A)

Uktolseja, J.C.B. 1989. The Status of the Indonesian Tuna Fisheries. Paper presented at the Third Southeast Asian Tuna Conference, 22-24 August. 1989. Denpasar, Bali, Indonesia.

Wahyuono, H. and Rusmadji. 1987. Lift net fishery in Jepara Waters. J. Penelitian Perikanan Laut 43: 81 . 87. 